\title{
Den historiske dimensjon i KRLE-faget
}

\section{Av Tarald Rasmussen}

Artikkelen ser noermere på den nye loereplanen for KRLE-faget med utgangspunkt $i$ spørsmålet om hvordan en historisk dimensjon er ivaretatt. Planens forste "Kjerneelement" lanserer en globalt orientert religionsforståelse som - trass $i$ pretensjonen om å angi en «kjerne» - er videre og mer altomfattende formulert enn $i$ noen tidligere loereplan for faget. Denne åpne bestemmelsen av hva man skal arbeide med, går hånd $i$ hånd med en svekking av et historisk perspektiv som siden KRL-faget ble lansert $i$ 1997, har spilt en viktig rolle $i$ loereplanene. Et hovedspørsmål $i$ artikkelen er om en slik dreining i forståelsesform bidrar til å styrke eller til å svekke en dypere forståelse av religion $i$ skolen. Kan en slik dypere forståelse oppnås uten historisk arbeid med spesifikke religiøse tradisjoner?

Nøkkelord: KRLE, Historie, Tradisjon, Religionskritikk

TARALD RASMUSSEN, $f$. 1949, professor em. i kirkehistorie, Universitetet i Oslo, Leder av laereplangruppen for det første KRL-faget 1997. Adr: Arne Garborgs vei 24, 0671 Oslo, Epost:tarald.rasmussen@teologi.uio.no

KRL-faget ble innført som et nytt fellesfag i norsk skole i 1997. Siden har det vært langvarige diskusjoner både om fagets innhold og dets ideologiske profil. For å imøtekomme kritikk ble faget endret både i 2005, i 2008 og i 2015. Fra 2020 er faget blitt omarbeidet igjen, og denne gangen på en langt mer grunnleggende måte enn tidligere. Mens alle endringer av den opprinnelige KRL-læreplanen fram til 2015 med god rett kan betraktes som revisjoner av KRL-konseptet fra 1997, er læreplanen fra 2020 noe helt annet. En føring om at om lag halvparten av timetallet skal brukes på arbeid med kristendommen, er (av politiske grunner) blitt bevart, men tilnærmingen til hva som er faglig og pedagogisk sentralt i faget, er ny.

Denne artikkelen er først og fremst et forsøk på en tekstanalyse eller eksegese av noen sentrale deler av den nye læreplanteksten. ${ }^{1}$ Tekstanalysen følges så opp med noen refleksjoner over ulike forståelsesformer i arbeidet med religion. Fokus både for tekstanalysen og for de etterfølgende refleksjonene er spørsmålet om hvilken plass historien har og bør ha i arbeidet med å forstå religion.

Læreplantekster har juridisk status som forskrifter, og man må forutsette at hvert ord er veid nøye før en slik tekst legges ut i endelig form. KRL-planene

1 Artikkelen er en sterkt bearbeidet og utvidet versjon av et foredrag holdt på dansk-norsk seminar om religionsundervisning i dansk og norsk skole og læreruddanning på Lysebu i Oslo i november 2019.

Prismet - IKO-Forlaget 2020

Tilgjengelig på https://journals.uio.no/index.php/prismet. Publisert under CC BY-NC 4.0. Fagfellevurdert 
har siden den første kom ut i 1997, vært gjenstand for en rekke mer eller mindre detaljerte tekstanalyser. ${ }^{2}$ Slike analyser kan dels legge vekt på kvantitative forhold, ved å telle hvor mange kompetansemål som er viet ulike deler av faget, eller ved å telle hvor ofte bestemte nøkkelbegreper opptrer. I tillegg er det viktig å se nøyere på sentrale begreper i seg selv, se hvilke kontekster de brukes i, og hvordan nye nøkkelbegreper erstatter andre som har vært sentrale i tidligere KRL-planer. Begge disse tilnærmingene vil bli brukt i denne artikkelen. 2020-planen blir da dels analysert som en tekst som står på egne ben. Dels blir det analytiske blikket også skjerpet gjennom en sammenligning med en eller flere av de tidligere KRL-planene.

To religionsfaglige og fagdidaktiske spørsmål legger nærmere føringer på tekstanalysen: 1) Hvordan ivaretas en historisk dimensjon i arbeidet med religion og livssyn i den nye planen? 2) Hvordan henger planens tilnærming til religion sammen med tilnærmingen til historien i den nye læreplanen? Artikkelen starter med en presentasjon av noen sentrale generelle føringer fra to offentlige utredninger og en stortingsmelding som anga retningen for arbeidet med nye læreplaner. Deretter kommer en detaljert analyse særlig av det første kjerneelementet og noen utvalgte kompetansemål i den nye KRLE-planen, før det analytiske blikket utvides til en bredere drøfting av funnene $\mathrm{i}$ tekstanalysen.

\section{GRUNNLAGSDOKUMENTER FOR NYE LÆREPLANER}

Det overordnete utgangspunktet for den pedagogiske nytenkningen i 2020-planverket har vært to innstillinger fra offentlige utvalg ledet av Sten Ludvigsen: NOU 2014:7: «Elevens læring i fremtidens skole. Et kunnskapsgrunnlag» og NOU 2015:8, «Fremtidens skole. Fornyelse av fag og kompetanser». De to innstillingene ble fulgt opp med Stortingsmelding 28 (2015-2016): «Fag - Fordypning - Forståelse. En fornyelse av Kunnskapsløftet.» Disse tre tekstene dannet det ideologiske grunnlaget for arbeidet med nye læreplaner.

Et sentralt begrep $\mathrm{i}$ alle disse grunnlagsdokumentene er «dybdelæring». Dybdelæringen som skal fremmes i de nye planene, settes i motsetning til «overflatelæring», som man ser ut til å mene at har preget mange tidligere læreplaner.

NOU 2014:7 går aller mest detaljert til verks. En stor oversikt på s. 36 presenterer dikotomien mellom de to måtene å lære på. De tre første motsetningsparene er formulert som følger: Innen dybdelæring gjelder: «Elever relaterer nye ideer og begreper til tidligere kunnskap og erfaringer». Innen overflatelæring gjelder: «Elever jobber med nytt lærestoff uten å relatere det til hva de kan fra før». Innen dybdelæring gjelder: «Elever organiserer egen kunnskap i begreps-systemer som henger sammen». Innen overflatelæring gjelder: «Elever behandler lærestoff

2 Et tidlig eksempel er Stange 1999. Innslag av tekstanalyse finner man også hos Gravem 2004. I nyere forskningsbidrag til religionsfaget i norsk skole spiller detaljerte læreplananalyser gjerne en mindre rolle. Et eksempel er Sødal, Hodne, Repstad og Tallaksen 2018. Etter lanseringen av 2020-planen kan det igjen være mer relevant å gi seg inn på slike analyser. 
som atskilte kunnskaps-elementer». Innen dybdelæring gjelder: «Elever ser etter mønstre og underliggende prinsipper». Innen overflatelæring gjelder: «Elever memorerer fakta og utfører prosedyrer uten å forstå hvordan eller hvorfor».

NOU 2015:8 følger opp med blant annet følgende karakteristikker (s. 33): Dybdeloering inneborer at elevene gradvis utvikler sin forståelse av begreper og sammenhenger innenfor et fag eller på tvers av fag. ... Overflatelaring, som kontrast til dybdelaring, kjennetegnes av innlaering av faktakunnskap uten at eleven setter kunnskapen i en sammenheng. Overflatelaring knyttes til et syn på undervisning som kunnskapsoverføring der den aktive eleven ikke står $i$ sentrum for loeringen.

For å fremme dybdelæring, skal man nå begrense detaljstyring og antall kompetansemål, som hadde vært tallrike i alle de tidligere planene, og aller mest i den første KRL-planen fra 1997. I stedet skal man fremme konsentrasjon ved å formulere såkalte «kjerneelementer» som skal gi fokus for det faglige arbeidet i skolen. Disse kjerneelementene skal erstatte tidligere læreplaners angivelse av «hovedområder».

$\AA$ formulere slike kjerneelementer fikk høyeste prioritet i arbeidet med nye planer, og det skulle skje i en egen prosess forut for arbeidet med resten av læreplanene. Kjerneelementene skulle - som navnet tilsier - vise vei til det som skulle være «fagets kjerne». For å klare dette, skulle de sette navn på «Big ideas» eller nøkkelbegreper fra det aktuelle fagområdet. De skulle vise hva som er det viktigste $i$ faget, og samtidig gi signaler om emner og områder som ikke skulle prioriteres like høyt. ${ }^{3}$

På denne måten ville også lærerne få større frihet både til å treffe egne valg og til å gå dypere inn i enkelte temaer og ta lettere på andre. Ett resultat av fokus på dybdelæring og kjerneelementer var at arbeid med historiske emner måtte få en redusert plass i flere fag der de før har vært viktige. Religionsfaget hører til de fagene som skulle endres i en slik retning. Den sentrale kjernen i faget skulle nå være «en grundig og bred religionsforståelse», og det man omtalte som «faktakunnskap og historiekunnskap om enkeltreligioner» skulle tre mer i bakgrunnen.

Den viktigste endringen i fagene KRLE og religion og etikk er at vi går bort fra å organisere fagene med utgangspunkt $i$ verdensreligionene, og heller bygger opp fagene tematisk med vekt på at elevene skal utforske og forstå. Bakgrunnen for dette er at gjeldende lareplaner legger veldig stor vekt på faktainnhold. En grundig og bred religionsforståelse er viktigere enn at alle elever sitter inne med akkurat samme faktakunnskap og historiekunnskap om enkeltreligioner. ${ }^{4}$

3 Sml. for eksempel innledningen fra Hedda Huse (Huse 2017) i Utdanningsdirektoratet, der hun ved oppstarten av læreplangruppenes arbeid med å formulere de nye planenes kjerneelementer 12. - 13.06.2017 skulle utdype hvordan disse skulle bidra til å fremme dybdelæring: «Ulike perspektiver på kjerneelementer og koblinger til kompetansebegrepet og dybdelæring $»$. Om «Big ideas» i religionsundervisningen, se Wintersgill 2017.

4 Sml. Utdanningsdirektoratet kunngjøring «Hva er nytt i fagene» om KRLE 


\section{Kuerneelement 1 og 2}

Da første fase av læreplanarbeidet var ferdig våren 2018, hadde det fornyede KRLE-faget fått definert fem kjerneelementer. «Kjerneelementer er det viktigste elevene skal lære i hvert fag. Arbeidet med kjerneelementer var et forarbeid til utvikling av læreplanene.» (Utdanningsdirektoratet om Kjerneelementer 2017) Markeringen av et nytt utgangspunkt og en ny orientering i forhold til tidligere læreplaner i faget er særlig tydelig i de to første kjerneelementene.

1 Kjennskap til religioner og livssyn

Faget skal gi kunnskap om og forståelse for kristendom og andre religioner og livssyn lokalt, nasjonalt og globalt og på individ-, gruppe- og tradisjonsnivå. Elevene skal også få innsikt $\mathrm{i}$ hvordan kristendom og andre religioner og livssyn inngår i historiske prosesser og henger sammen med samfunnsendringer og kulturarv. Elevene skal bli kjent med mangfoldet av religioner og livssyn, og de ulike tradisjonenes indre mangfold. Faget skal gi grunnlag for refleksjon over majoritets-, minoritets- og urfolksperspektiver i Norge.

2 Utforsking av religioner og livssyn med ulike metoder Elevene skal undersøke og utforske kristendom og andre religioner og livssyn som sammensatte fenomener gjennom bruk av varierte metoder. Deres forståelse av religioner og livssyn utdypes og utfordres gjennom analyse av og kritisk refleksjon over kilder, normer og definisjonsmakt. Kjennskap til ulike syn på og definisjoner av religioner og livssyn inngår i kjerneelementet og er vesentlig for å forstå og håndtere mangfold (KRLE-læreplanen 2020).

Disse formuleringene hadde vært nøye avveid etter at læreplangruppen hadde lagt fram sitt forslag som i sin tur var blitt kommentert fra flere hold før Utdanningsdirektoratet fastsatte ordlyden. Disse kjernetekstene skulle nå være grunnlaget og utgangspunktet for det videre arbeidet med læreplanen. Dermed må de også tåle en kritisk nærlesing. Hvordan hjelper disse tekstene til å sette fingeren på det viktigste elevene skal lære: hva som skal prioriteres i opplæringen og hva som kan settes til side, og hvordan ivaretar de fortsatt en historisk dimensjon, som ofte har spilt en sentral rolle i religionsfaget både i skolen og i akademisk sammenheng?

\section{SignalbegrePer FOR EN HISTORISK DimenSJON Tradisjon}

Kjerneområde 1 inkluderer flere begreper og formuleringer som markerer en historisk dimensjon. For det første kan det se ut som om «tradisjon» er blitt et nøkkelbegrep for å sette ord på et historisk perspektiv i faget: «Faget skal gi kunnskap (...) og forståelse (...) på individ-, gruppe- og tradisjonsnivå.» Sammenstillingen av disse tre begrepene «individ», «gruppe» og «tradisjon» kan 
synes litt merkelig, og begrepene kan innen rammen av historisk diskurs virke inkongruente: En «tradisjon» er per definisjon knyttet til historiske røtter og markerer på den måten i seg selv en historisk dimensjon. SNL definerer begrepet slik: «I alminnelig språkbruk betyr tradisjon kulturemner som er overført fra slektledd til slektledd gjennom tid» (Alver 2020). Det samme er ikke tilfelle med begrepene «individ» og «gruppe».

En slik tilsynelatende asymmetrisk sammenstilling av begrepene er ikke innlysende uten at man vet hvor den stammer fra. Alt taler for at den er overtatt fra den britiske religionsforskeren og pedagogen Robert Jacksons «Interpretive Approach» til religionsopplæring i skolen. Jackson har gjennom lang tid øvet en viktig innflytelse på norsk religionspedagogikk og religionsdidaktikk. ${ }^{5}$

Nettopp hos Jackson spiller sammenstillingen «individ - gruppe - tradisjon» en sentral rolle når han vil ha fram kompleksiteten i en religion. Alle disse tre tilnærmingene må til for å speile denne kompleksiteten. «Tradisjon» er da det mest overordnete nivået, men hos Jackson er tradisjon i overraskende liten grad knyttet til historie. I stedet er det et alternativt begrep til det overordnete navnet på en religion, for eksempel «kristendom», og det viktigste anliggendet med begrepet ser ut til å være å fange en religions mangfold eller kompleksitet på et overordnet nivå:

The term «religious tradition» is preferred to «religion», although it is recognised that some will prefer to use the latter term in a qualified way. Thus the Christian tradition encompasses all the different denominational and cultural manifestations of Christianity. Immediately it is clear that it would be impossible for any individual to have a full grasp of this. ${ }^{6}$

Man kan spørre om det er rimelig og riktig å bruke et så sentralt kjerneelementbegrep i en så innforstått mening; om det er rimelig og riktig å sette det i omløp med en «regelgivende definisjon» knyttet til Robert Jacksons forfatterskap. Man kan anta at begrepet kommuniserer greit på disse premissene til de fleste religionspedagoger og mange - men slett ikke alle - godt utdannede religionslærere i Norge. Samtidig vil nok mange andre lesere tolke det mer i retning av SNL-definisjonen, og tenke inn en historisk dimensjon i dette begrepet.

Sistnevnte tolkning vil være nærliggende ikke bare fordi det svarer til en «alminnelig språkbruk» (SNL), men også fordi det svarer til bruken av begrepet i «Overordnet del» av læreplanverket for 2020. Her står det i avsnittet om «Identitet og kulturelt mangfold»:

5 Et nokså ferskt eksempel er von der Lippe og Undheim 2017, der Jackson er på topp i antall henvisninger i bibliografien med 15 titler. Hans «interpretive approach» omtales særlig på s. 20. Jackson har ofte besøkt Norge, har to æresdoktortitler fra norske akademiske institusjoner, har vært gjesteprofessor i landet og blir hyppig henvist til i nyere norske religionsdidaktiske arbeider

6 Jackson 2009, s. 2. Takk til Gunfrid Ljones Øierud og Oddrun Marie Hovde Bråten for råd når det gjelder tolkning av Robert Jackson. 
Innsikt $i$ vår historie og kultur er viktig for utvikling av elevenes identitet og skaper tilhørighet til samfunnet. Elevene skal lære å kjenne de verdiene og tradisjonene som bidrar til å samle menneskene i landet. Kristen og humanistisk arv og tradisjon er en viktig del av landets samlede kulturarv og har spilt en sentral rolle for utvikling av vårt demokrati.

(Læreplanverket Overordnet del 2020)

I denne teksten, som er ment å gi overordnete føringer for alle læreplanene i det nye læreplanverket, er begrepet «tradisjon» åpenbart brukt mer i tråd med SNL-definisjonen, og med tydelig vekt på det historiske. Det kan dermed se ut til at begrepet her brukes på en helt annen måte enn i KRLE Kjerneelement 1. KRLE-planen knytter an til en spesifikk brukskonvensjon som en del av planens lesere vil kjenne til, men som vil være ukjent for andre. I læreplanverkets overordnete del brukes begrepet på en mer allment kjent måte. For tolkningen av planen representerer en slik uklarhet i bruken av et så sentralt begrep et problem.

Begrepet «tradisjon» brukes to ganger i Kjerneelement 1 . Ved siden av Jacksonsammenstillingen i linje 2 kan man litt lenger ned også lese at elevene skal «bli kjent med (...) de ulike tradisjonenes indre mangfold». Tolkningen av dette vil i stor grad avhenge av om man forstår tradisjonsbegrepet à la Jackson eller à la SNL. Velger man det første (og det er ut fra nærkonteksten det mest nærliggende), bør vekten legges på et samtidsorientert mangfold representert innen rammen av det som betegnes med overordnete merkelapper som «kristendom», «islam» eller «hinduisme». Velger man i stedet en mer historisk orientert lesing av begrepet «tradisjon», slik fjernkonteksten med læreplanverkets Overordnete del kan sies å legge opp til, vil denne formuleringen i mye høyere grad være en invitasjon til å prøve å forstå de ulike religionenes indre mangfold i et historisk lys: altså med hvordan de gjennom tiden er blitt delt opp i ulike retninger og partier, og hvordan ulike grupper eller fraksjoner har tolket sin religion eller sitt livssyn på ulike måter.

En avgjørende målsetting med å formulere «kjerneelementer» i læreplanene er å legge til rette for dybdelæring, og det kan være fristende å spørre hvilken av de to tilretteleggingene av tradisjonsbegrepet som legger best til rette for en dypere forståelse av indre mangfold i en religion. Er det et samtidsorientert blikk som legger vekt på bredden og mangfoldet i hvordan en religion er representert, eller er det en mer historisk vinklet tilnærming som også prøver å forstå og forklare hvordan det mangfoldet man kan observere, er vokst fram og blitt til? Man kan lett tenke at det nettopp er dette siste som ofte vil være best egnet til fokusert dybdelæring for å fremme forståelse, slik de nye læreplanene generelt legger opp til. Mens en ambisjon om å «bli kjent med» en tradisjons indre mangfold i et samtidsorientert perspektiv lettere vil føre til «overflatelæring». Anvender man distinksjonen på den kristne religion, kan man dermed spørre om man virkelig 
forstår det «indre mangfoldet» i kristendommen, representert for eksempel i skillet mellom protestantisk og katolsk eller mellom reformert og baptistisk, uten å nærme seg dette mangfoldet historisk og se hvordan det oppsto. Vil ikke en tilnærming til slike spørsmål med hovedvekt på hvordan alt ser ut i dag, lett føre til lite forståelse og lite dybdelæring? Man kan observere at noen har utformet sin religion slik og noen slik, men for å finne svar på hvorfor, må man gjerne ty til historien.

\title{
«Kulturarv»og «historiske prosesser»
}

Ved siden av begrepet «tradisjon», som i læreplanteksten altså er brukt på en tvetydig og uklar måte, finner man også en mer utvetydige henvisning til historisk arbeid i Kjerneelement 1. Det står at elevene skal «få innsikt i hvordan kristendom og andre religioner og livssyn inngår i historiske prosesser og henger sammen med samfunnsendringer og kulturarv». Nøkkelbegrepene her er «historiske prosesser» og «kulturarv». Man kan lese setningen som en invitt til å arbeide med et svært aktuelt spørsmål i dagens samfunn: nemlig spørsmålet om hvor skillet går mellom kultur og religion. Men bruken av begrepet «kulturarv» peker samtidig i en annen retning: Dette begrepet brukes gjerne som et verdiladet begrep, som inkluderer både «materiell og immateriell arv som er verd å verne og ta vare på». ${ }^{7}$ «Overordnet del» av det nye læreplanverket angir en kontekst for å tolke formuleringen i en slik retning. Der står det under punkt 1,2: «Identitet og kulturelt mangfold»:

\begin{abstract}
Kristen og humanistisk arv og tradisjon er en viktig del av landets samlede kulturarv og har spilt en sentral rolle for utvikling av vårt demokrati. Den samiske kulturarven er en del av kulturarven $i$ Norge. Var felles kulturarv har utviklet seg gjennom historien og skal forvaltes av nålevende og kommende generasjoner. (Lareplanverket Overordnet del 2020)
\end{abstract}

Samtidig skimter man også her en spenning mellom det som står om kulturarv i læreplanverkets overordnete del og formuleringen om kulturarv i KRLE-planen. Den overordnete delen er utvilsomt formulert for å ivareta det som står i Opplæringslovens formålsparagraf:

Opplaringa skal byggje på grunnleggjande verdiar $i$ kristen og humanistisk arv og tradisjon

(...) Oppleringa skal bidra til å utvide kjennskapen til og forståinga av den nasjonale kulturarven og vår felles internasjonale kulturtradisjon.

(Opplæringslovens formålsparagraf)

7 Nærmere eksempler på hvordan begrepet brukes i Norge i dag kan man for eksempel finne på hjemmesiden til stiftelsen Norsk Kulturarv. I L97 var «kulturarv» et sentralt begrep for hvordan elevene skulle arbeide historisk med kristendommen: Elevene skulle få «grundig kjennskap til Bibelen og kristendommen som kultur$\operatorname{arv} \ldots \gg$ 
Man ser fort at det er et sprik mellom det som står om «kulturarv» i opplæringslov og i Overordnet del på den ene siden og det som står om «kulturarv» i KRLE-planen. Mens de to første framhever den nasjonale kulturarven med formuleringene «kristen og humanistisk arv» og «den nasjonale kulturarven», er dette tonet ned i KRLE-planen. Der blir det nasjonale stilt på sidelinjen, og kulturarvperspektivet gjemt bort langt inne i en kryptisk og overlesset setning om hvordan religioner og livssyn i sin alminnelighet «inngår i historiske prosesser og henger sammen med samfunnsendringer og kulturarv».

Hva betyr det at religioner og livssyn «inngår i historiske prosesser»? Hva betyr det at religioner og livssyn «henger sammen med samfunnsendringer»? Og hva betyr det at religioner og livssyn «henger sammen med kulturarv»? Gir slike formuleringer håndterbare føringer for hvordan man skal arbeide med religion $\mathrm{i}$ dette faget? Er tanken for eksempel at når man skal se på hvordan religion «inngår i historiske prosesser og henger sammen med samfunnsendringer», må man også rette et eget blikk på slike prosesser og samfunnsendringer? Hva betyr det i praksis? For å ta reformasjonen som eksempel: Forventer man her at man i skolen skal gå lenger enn man gjerne har pleid å gjøre $i$ å kontekstualisere reformasjonen som religiøs endring? Og hjelpe elevene til å forstå hvordan reformasjonen er innrammet av samfunnsendringer som framveksten av sterkere fyrstestater, selvstendige forfatninger for riksbyer i Sør-Tyskland, boktrykkerkunst, økt fokus på individuell religiøsitet utenfor klostrene i senmiddelalderen osv.?

Kanskje kan man heller si at sammenstillingen av alle disse temmelig vage og allmenne selvfølgelighetene i én og samme setning gir hjemmel for å holde på med nesten hva som helst i dette faget. Og det var vel ikke meningen med å formulere kjerneelementer?

Hvilken prioritering, hvilken konsentrasjon?

Også om man utvider det analytiske blikket på teksten i Kjerneelement 1, blir det påtrengende å spørre: Hva er det her som peker i retning av noen form for faglig konsentrasjon, en kjerne som man kan fokusere arbeidet i faget om, «det viktigste elevene skal 1ære»? Man skal konsentrere seg om a) alle religioner og livssyn, behandle dem b) på lokalt, nasjonalt og globalt nivå, og i tillegg c) på individ, gruppe og tradisjonsnivå. Fins det her i det hele tatt noe som ikke er inkludert og tenkt inn?

Det som er prioritert i det nye faget, er ifølge Utdanningsdirektoratet «En grundig og bred religionsforståelse» (se fotnote 4). Hvordan svarer de to første kjerneelementene på hvordan man skal nærme seg et slikt mål? Hva er nøkkelbegrepene som viser vei til dybdelæring om religion med slik «grundig og bred religionsforståelse» som overskrift? Finner man flere holdepunkter for et svar ved 
å se på formuleringene i kjerneelement 2? Lite tyder på det. Det andre kjerneelementet er like åpent formulert som det første. Det legges vekt på at elevene skal «utforske kristendom og andre religioner og livssyn som sammensatte fenomener gjennom bruk av varierte metoder», og ha «kjennskap til ulike syn på og definisjoner av religioner og livssyn». Her er igjen få spor av nøkkelbegreper fra de underliggende fagtradisjonene, og lite hjelp til faglig fordypning og fokusering.

\section{Fra kJERNEELEMENTER TIL KOMPETANSEMÅL}

Nå er det klart at man ikke bare kan granske formuleringen av kjerneelementer når man undersøke hvilken vekt som legges på historien i den nye KRLE-læreplanen. Man må se på hele planen.

Kjerneelementene er preget av at man ønsker å ta utgangspunkt $i$ en bred, fenomenologisk og antropologisk orientert, religionsforståelse. I tidligere læreplanarbeid har man gjerne tenkt at en slik tilnærming til fenomenet religion kan passe bedre på videregående skole enn i grunnskolen. ${ }^{8}$ I stedet for en overordnet systemorientert tilnærming til det mangfoldige fenomenet religion og livssyn, har man på de lavere klassetrinnene i høyere grad prioritert å tenke nedenfra, og starte med religionenes manifestasjoner: i ritualer, i fortellinger og myter, i normer og verdier.

\section{Fenomen vs. fortelling}

Dette kunne man bygge opp ut fra en erfaringsbasert tilnærming på de lavere trinnene, og så nærme seg overordnete forståelsesrammer og sammenligninger på de høyere trinnene. På denne måten ble basis for læringen noen konkrete møter og etter hvert noen rammefortellinger både om kristendommen og de andre store religionene. Disse rammefortellingene ble mer omfattende og komplekse jo høyere man kom i klassetrinnene. Historisk arbeid med religionene spilte en særlig viktig rolle på de mellomste klassetrinnene, og bidro både til å gjøre en religiøs tradisjon levende og konkret og til å til å vise mangfoldet i de ulike religiøse tradisjonene. Når elevene så skulle ta fatt i fenomenet religion igjen det siste året på videregående skole, kunne det de hadde lært på de tidligere klassetrinnene danne grunnlag for en mer systemorientert tilnærming.

Nå ser det ut til at man nesten legger opp til å snu alt dette på hodet, slik at det overordnete fenomenet «religion og livssyn» helt fra de laveste trinnene av skal danne utgangspunkt for opplæringen. Hvordan man tenker seg dette operasjonalisert, ser man mer av når man gransker den nye planens kompetansemål. Sammenlignet med 2015-planen for KRLE er antallet kompetansemål redusert

8 I læreplanen for Religion og etikk i videregående skole fra 2006 er det første hovedområdet definert som følger: «Religionskunnskap og religionskritikk: Hovedområdet religionskunnskap og religionskritikk handler om utbredelsen av religioner og livssyn både globalt, nasjonalt og lokalt. I hovedområdet introduseres analyseverktøy som grunnlag for en helhetlig og balansert forståelse av de enkelte religionene. Hovedområdet dreier seg også om grunnleggende spørsmål knyttet til religionenes rolle i samfunnet.» 
fra 130 til 41. De 41 kompetansemålene er jevnt fordelt i tre grupper (etter 4. trinn, 7. trinn og 10. trinn).

En første iøynefallende observasjon ved sammenligning mellom 2015-plan og 2020-plan er at begrepet «fortelle»/»fortelling» er tonet kraftig ned i den nye planen. En fortellingsdidaktisk tilnærming til religionsfaget i skolen har spilt en viktig rolle siden KRL-faget ble innført i 1997, og alle tidligere revisjoner av planen har speilet dette. ${ }^{9}$ Religionenes fortellinger har hatt og har avgjørende betydning for å konstituere dem både som «tradisjon» og som «kulturarv». De er derfor viktige som bidrag til å utdype den historiske dimensjonen i faget. Dessuten har det vært mulig å nærme seg alle de store verdensreligionene (om enn i mindre grad livssynshumanismen) på denne måten: de store religionene har alle sine fortellinger både fra svært gammel og fra nyere tid, og disse fortellingene har vært med på å gjøre de religiøse tradisjonene til det de er. Mobilisering av slike fortellingstradisjoner både i skolen og i lærerutdanningen har siden KRL-faget ble innført, vært en viktig strategi for å videreutvikle religionsfaget i norsk skole til et inkluderende fag.

I 2020-planen merker man imidlertid en endring her. Kompetansemålene på mellomtrinnet i 2015-planen bruker ordet «fortelling/fortelle» ni ganger, spesifisert på alle de store religionene i planen. I 2020-planen er begrepet helt borte fra kompetansemålene på mellomtrinnet. ${ }^{10}$ Sentralord er i stedet «rituelle praksiser og etiske normer» som skal «beskrives og presenteres».

\section{Samlebegreper vs. individualitet}

En annen iøynefallende endring er at alle religioner og livssyn er slått sammen også i de enkelte kompetansemålene. I alle tidligere planer siden 1997 har man hatt spesifiserte kompetansemål for de enkelte religionene. Slik fikk man fokus på den enkelte religions (eller tradisjons, for å si det med Robert Jackson) individualitet. Trass i rammebestemmelsen om at halvparten av tiden i faget skal brukes til arbeid med kristendommen, er bare to av 41 kompetansemål (ett etter 4. trinn og ett etter 7. trinn) siktet spesifikt inn mot arbeid med denne religionen. I tillegg er ett viet livssynshumanisme, ett er viet samisk religion og urfolksreligion, og ett er viet «religiøst mangfold og religiøse praksiser utenfor etablerte religionssamfunn». Alle andre kompetansemål som omhandler religion og livssyn er formulert i mer overgripende og generelle ordelag, og omhandler «kristendom og andre religioner og livssyn», «østlige og vestlige religiøse tradisjoner» eller «religioner og livssyn».

9 Fortellingens sentrale plass i faget ble tidlig framhevet også i forskningslitteraturen. Et viktig eksempel er $I$ begynnelsen var fortellingen (Breilid og Nicolaisen 2011). Denne boka kom først ut i 2000, og igjen i ny revidert utgave i 2011. Også Nasjonalt Læremiddelsenters Kildesamling til KRL-faget (Rasmussen og Thomassen 1999 ) viet stor plass til presentasjon av fortellingsstoff fra ulike religiøse tradisjoner.

10 Begrepet forekommer i kompetansemålene for 4. trinn, der det er tale om å «samtale om og presentere sentrale fortellinger og trosforestillinger». 
Denne typen formuleringer går igjen i 20 av de 41 kompetansemålene.

En slik overveldende dominans av kompetansemål som formulerer seg allment om religion, speiler kjerneelementenes språkbruk, der det faglige innholdet konsekvent omtales ved bruk av formuleringen «kristendom og andre religioner og livssyn». Tilsvarende formuleringer går igjen når planen taler om forventet elevkompetanse på de ulike nivåene. Etter 4. trinn står for eksempel følgende: «Elevene viser og utvikler kompetanse i KRLE på 1.-4. trinn når de formidler kunnskap om religioner og livssyn fra nærmiljøet og omverdenen.»

\section{HisTORISK DIMENSJON}

En slik generaliserende språkbruk legger ikke godt til rette for historisk arbeid, som svært ofte er orientert om det individuelle, det spesifikke. Begrepet «historie» eller «historisk» dukker da også kun opp i to av planens 41 kompetansemål. Etter 7. trinn skal elevene kunne «giøre rede for historien til kristendom og andre religioner og livssyn i Norge, inkludert samers og nasjonale minoriteters religionsog livssynshistorie», og etter 10. trinn skal de kunne «utforske og drøfte hvordan kristendom og andre religioner inngår i historiske endringsprosesser globalt og nasjonalt».

I tillegg til disse to kompetansemålene inneholder planen 8 kompetansemål der begrepet «tradisjon» er anvendt, som etter 10. årstrinn: «gjøre rede for og reflektere over samenes og andre urfolks religions- og livssynstradisjoner», eller det temmelig kryptisk formulerte kompetansemålet etter 7. årstrinn: «utforske og sammenligne tekster og materielle uttrykk som kilder til kunnskap om kulturarv knyttet til kristendom og ulike religions- og livssynstradisjoner».

Det er, som vi allerede har vært inne på, ikke klart om planen legger opp til at «tradisjoner» skal bearbeides som historie (hvilket de jo er), eller bare som historisk arv slik den manifesterer seg for oss i dag (hvilket de også er). Dette er en viktig uklarhet, som gjør tolkningen av planen vanskelig. Legger man en historisk dimensjon inn i alle kompetansemålene der begrepet «tradisjon» er brukt, er man på vei mot noen globalhistoriske pretensjoner som er umulige å oppfylle i praksis. Mer nærliggende blir det ut fra en slik tankegang kanskje å tenke seg at den historiske dimensjonen i faget særlig flagges i de to kompetansemålene der ordet «historie» brukes eksplisitt. Med en slik lesing framstår planen som en radikal reduksjon av en historisk læringsdimensjon, som nå også er «snakket ned» i de nasjonale føringsdokumentene der historisk kunnskap på en problematisk måte knyttes sammen med «overflatelæring».

\section{Dybdelæring og «historien bak»}

Men er det først og fremst unødig faktakunnskap og «overflatelæring» det historiske arbeidet med faget har hatt å by på? Er det grunnlag for å tenke at 
historisk kunnskap i religionsfaget mest har fungert som huskestoff som skulle reproduseres? Er det slik at dybdelæring og forståelse er blitt bedre fremmet ved at man har gått direkte løs på de store temaene i en samtidsorientert sammenheng, uten bakveier og omveier om historien?

Målet med «dybdelæringen» i de nye læreplanene skal være å fremme forståelse. Når man arbeider med religion, oppdager man rett som det er at man trenger et historisk perspektiv nettopp for å komme fram til en bedre forståelse av det man i første omgang ser. Skal man forstå hvorfor prester og biskoper og til og med en pave har en så sentral rolle i katolsk kristendom, må man se nærmere på historien. Det samme gjelder dersom man vil få en dybdeforståelse av hvorfor katolsk kristendom fortsatt er så avvisende til at kvinner kan bli prester. Skal man nærme seg en dybdeforståelse av hvorfor islam er splittet i shiaer og sunnier, er man også avhengig av en historisk tilnærming. Det samme gjelder om man vil forstå hvorfor kristne i Midt-Østen er så forskjellige fra kristne i Nord-Europa, - bare for å ta noen eksempler. Det fins nesten alltid «en historie bak», og denne historien er som oftest noe helt annet enn «overflatekunnskap».

\section{Historie og historisk kritikk}

Historisk arbeid har hatt og har ulike funksjoner innen rammen av religionsstudiet. Det kan bidra til å gjøre en religiøs tradisjon levende og bringe den nær, til å vise mangfoldet $i$ en religiøs tradisjon, til å styrke egen tradisjons legitimitet og betydning, eller også til det stikk motsatte: til å kritisere og dekonstruere historisk tradisjon. Fram til 1700-tallet fungerte henvisninger til historien både i skole og ved universitet mest som henvisninger til en autoritetsinstans. For det første fant man i historien religionens normative kilder, for det andre representerte historien i seg selv flere steder også en normativ tradisjon som var del av religionens grunnlag. Innen for eksempel jødedom, islam eller katolsk kristendom har tradisjonen på denne måten vært tillagt mye større autoritet enn tilfellet har vært for eksempel i protestantisk kristendom eller i livssynshumanisme.

Utover på 1800-tallet vant historisk religionsforskning fram som kritisk disiplin især ved tyske universiteter preget av en protestantisk religionsforståelse. En sentral oppgave var her å problematisere og dekonstruere religiøse autoritative tradisjoner. Dette kom i første omgang til uttrykk som bibelkritikk. En av pionérene på dette området var Ferdinand Christian Baur midt på 1800-tallet $\mathrm{i}$ Tübingen: Han var en av de aller første som leverte vitenskapelige begrunnelser for at Det nye testamente (NT) ikke kunne ansees som en enhetlig og harmonisk autoritetstekst. Tvert om speilet NT ulike motstridende tradisjoner, forankret i ulike partier blant de tidligste kristne. Et par generasjoner senere var Adolf von Harnack i Berlin en frontfigur for den protestantiske tradisjonskritikken. Et hovedanliggende for ham var å dekonstruere kristne dogmer som historisk betinget 
tradisjon, som man dermed også burde forholde seg kritisk til. Både Baur og Harnack arbeidet historisk-kritisk i forlengelse av et hovedanliggende i reformasjonen på 1500-tallet, der Luther hadde kritisert pavekirkens tradisjonsforståelse som uttrykk for kirkelig egeninteresse mer enn for ekte religion.

2020-læreplanen har som vi har sett en forkjærlighet for begrepet «tradisjon» når den skal sette navn på hva en religion er. Samtidig er det påfallende at planen nesten ikke bruker begrepet «kritikk» eller «kritisk». Ordet dukker opp i ett kompetansemål etter 10. trinn, men da utelukkende som betegnelse for det mest elementære nivået for kritikk, nemlig kildekritikk. ${ }^{11}$ Religionskritikk i mer omfattende forstand, enten som tradisjonskritikk eller som helt grunnleggende religionskritikk, står det ingenting om. Alle religiøse tradisjoner og alt religiøst mangfold tas på «face value».

Et kritisk blikk på tradisjonene har vært og er sentralt i store deler av religionsforskningen, og det har ofte vært nær knyttet sammen med den historiske tilnærming til religiøse tradisjoner. Et slikt blikk kan avdekke religiøse tradisjoner som mer komplekse og motsetningsfylte enn man ønsker å tro. Det kan også avdekke religiøse tradisjoner som uttrykk for makt og egeninteresse. Man kan spørre seg om det ikke ville vært en rimelig videreføring av religionsforskningens kritiske perspektiv i en læreplan anno 2020 å ta bedre vare på slike kritiske perspektiv. Tradisjonskritikk og mer grunnleggende religionskritikk er i dagens samfunn ikke blitt mindre viktig.

\section{Historien om religion i Norge}

Den nye læreplanens brede, allmenne og globale tilnærming til fenomenet «religion og livssyn» legger i mindre grad opp til å utforske de store og små historiene om spesifikke religiøse tradisjoner. Det finnes ingen stor fortelling eller historie om religion og religiøst mangfold på globalt nivå, som ser ut til å være en sentral «Big idea» i planen. Men det finnes mange små og mellomstore historier både om enkeltreligioner og om møter mellom religioner som lett kan få en annen status enn tidligere i lys av denne læreplanen.

Især er denne endringen av overordnet perspektiv en utfordring i forhold til historien om religion i Norge. Selv om den er framhevet i planens overordnete del og i formålsparagrafen, henger den i selve læreplanen nå mest på ett kompetansemål etter 7. trinn. ${ }^{12}$ Denne historien er viktig ikke bare for dem som sokner til den kristne religion, men også for andre. Den gir hjelp til å forstå hva som skjer med andre religioner når de slår rot i Norge, hvordan de så å si blir tilpasset norske forhold og blir «protestantisert».

En fare med en så åpen læreplan med svekket historisk basis er at religion

11 «... sammenligne og vurdere kritisk ulike kilder til kunnskap om religioner og livssyn»

12 Kompetansemål 1: «gjøre rede for historien til kristendom og andre religioner og livssyn i Norge, inkludert samers og nasjonale minoriteters religions- og livssynshistorie» 
formidles for mye som «fenomen» med illustrasjoner, eller et utall av små historier som alle er like relevante for å illustrere fenomenet «religion». Dette «fenomenet» er i dag trolig enda mer flytende og udefinerbart enn det læreplanen legger opp til. En ting man i dette store uvisse savner, er et orienteringspunkt i én stor grunnfortelling, som man både kan identifisere seg med (fordi den er relatert til Norge) og som man kan forholde seg kritisk til.

Historien om «Religion i Norge» handler selvsagt ikke bare om det lutherske. Den handler også om det førkristne/norrøne, om det katolske, om frikirker, om jøder og om muslimer, om livssynshumanisme og samisk religion. Fenomenet «religion og livssyn» står i fare for å bli forvirrende diffust og/eller svært abstrakt om man ikke lenger kan relatere det til og spille på en slik grunnfortelling som referanse, med en tydeligere plassering i planen enn nå (med ett av 41 kompetansemål).

\section{KONKLUSJON: LÆREPLAN OG FORSTÅELSESFORMER. Historie og INDiVidualitet}

På grunnlag av analysene i det foregående kan man skissere en nokså tydelig utviklingslinje når det gjelder historiens plass i KRL(E)-faget. Da faget ble lansert i 1997, spilte kristendommens historie en viktig rolle i læreplanen. Den var spesifisert til en rekke temaer som skulle tas opp i timene, og den hadde aller størst plass på mellomtrinnet.

Kompetansemålene for de andre verdensreligionene var i langt høyere grad preget av en samtidsorientering. Begrunnelsen for en slik forskjellsbehandling var den gangen rent pragmatisk (og ikke ideologisk eller prinsipiell): Kristendommen var da som nå den religionen som hadde størst plass til rådighet $\mathrm{i}$ undervisningen, og det ga anledning til også å tenke historisk om denne religionen. En presentasjon også av de andre verdensreligionene i historisk lys, med fordypning i hvordan de hadde endret seg og hvordan indre mangfold var oppstått, ville sprenge alle rammer for undervisningen i faget.

I 2008-planen så dette annerledes ut. ${ }^{13}$ Som del av bestrebelsene på likebehandling var en historisk tilnærming her foreskrevet også for de andre verdensreligionene. Ikke bare kristendommen, men også de andre store religionene skulle behandles med vekt på deres historie.

I de siste årene, fram mot 2020-1æreplanen, er det vokst fram en stadig tydeligere kritikk mot hele det såkalte «verdensreligion-paradigmet» (Anker 2017). Noe av grunnlaget for kritikken har vært at religionene her, trass $\mathrm{i}$ intensjoner om det motsatte, blir kategorisert inn i for rigide båser, slik at religiøst mangfold både innen de enkelte religionene og religionene imellom kommer til kort. Det kan altså se ut til at innføring av et historisk blikk på flere av verdensreligionene ikke

13 Her er et historisk perspektiv tydelig inne også for de andre verdensreligionene, især i kompetansemålene etter 10. årstrinn. 
i tilstrekkelig grad har bidratt til å formidle et slikt blikk på religiøst mangfold.

Et farvel til «verdensreligion-paradigmet», kombinert med et ideal om størst mulig likebehandling av religioner og livssyn, fører lett til at den historiske dimensjonen i faget svekkes. Ludvigsen-utredningens innføring av pedagogiske idealer om «Big Ideas» kan her kobles sammen med en fenomenologisk (og antropologisk) tilnærming til selve grunntemaet «religion», der historiens rolle først og fremst blir å illustrere, og ikke forklare, mangfold.

Denne utviklingen i faget gjennom de siste 23 årene illustrerer et dilemma. Historisk arbeid bidrar ikke bare med historisk kritikk av religiøse tradisjoner. Slikt arbeid bidrar også til å utdype det spesielle ved en religion. I tidligere historisk metodelære kalte man dette gjerne for individualitet, og et sentralt mål for historiefaget (mer enn for samfunnsfagene) var å utdype en nasjons, en religiøs tradisjons, eller - i biografisk sammenheng - en persons individualitet (Oexle \& Rüsen 1996). Denne individualiteten kunne gjerne være kompleks og motsetningsfylt, og den kunne ofte beskrives enda bedre ved å ta historisk komparasjon til hjelp (Green 2004). Men målet med komparasjonen var først og fremst å forstå det individuelle og det spesielle bedre. Ikke minst $\mathrm{i}$ arbeidet med å tolke religioner som islam, jødedom og kristendom, med tung og spesifikk historisk forankring, har en slik tilnærming vært sentral.

Det er viktig å se at historisk arbeid med sikte på å forstå individualitet er noe annet enn det religionsvitere fortsatt, ved bruk av en litt forenklet distinksjon, av og til hevder at teologien er opptatt av, nemlig å forstå religion «innenfra» (i motsetning til religionsvitenskapen, som forstår «utenfra»). ${ }^{14}$ Historisk arbeid for å forstå individualitet har ikke noe med denne distinksjonen å gjøre, og kan sikkert - like mye som teologisk arbeid - foregå både «innenfra» og «utenfra». Hovedsaken er at en historisk tilnærming er av vesentlig betydning for å forstå individualitet. Kanskje er det også tilfelle at en adekvat forståelse av flere av de religiøse tradisjonene ikke er mulig uten også å anlegge et slikt perspektiv og satse på en slik forståelsesform. Det har med egenarten og også med selvforståelsen til det man ønsker å forstå å gjøre, og forståelsen må tilpasses det man ønsker å forstå dersom man skal komme riktig «på skuddhold».

I en fenomenologisk og antropologisk forståelsesform, som preger den nye KRLE-planen, har behovet for å forstå det individuelle en underordnet plass. Hovedmålet er å forstå det overordnete fenomenet religion, med tilhørende variasjoner og mangfold. Det er ingen tvil om at også dette er en legitim og viktig forståelsesform når man skal arbeide med religion. Et relevant spørsmål er likevel hvor godt den passer som utgangspunkt for arbeid med religion i grunnskolen, og $i$ hvor stor grad den faktisk vil bidra til det som er de nye læreplanenes overordnete mål: nemlig konsentrasjon og «dybdelæring» heller enn «overflatelæring».

14 Von der Lippe og Undheim 2017 avstår i sin differensierte og gode drøfting s. 16f. fra å henvise til denne distinksjonen. Hos Hafnor og Kalvig 2020 dukker den imidlertid opp igjen, s. 22. 
Selv om en ny læreplan er en viktig føring for arbeidet i skolen, er det ikke slik at den bestemmer alt. En fordel med den nye planen er at den i stor grad åpner for valg, både for de som skal utvikle læremidler og for lærere.

\section{Kildetekster}

Læreplanverket L97 Permalink: https://urn.nb.no/URN:NBN:no-nb_ digibok_2008080100096

Læreplan Religion og etikk, Videregående skole, 2006. http://data.udir.no/kl06/ REL1-01.pdf

KRLE læreplan 2015 http://data.udir.no/kl06/RLE1-02.pdf

NOU 2014:7: Elevens læring i fremtidens skole. Et kunnskapsgrunnlag. https://www.regjeringen.no/contentassets/e22a715fa374474581a8c58288edc161/no/pdfs/nou201420140007000dddpdfs.pdf

NOU 2015:8: Fremtidens skole. Fornyelse av fag og kompetanser. https://www. regjeringen.no/contentassets/da148fec8c4a4ab88daa8b677a700292/no/ pdfs/nou201520150008000dddpdfs.pdf

Stortingsmelding 28 2015/16: Fag - Fordypning - Forståelse. En fornyelse av Kunnskapsleftet. https://www.regjeringen.no/no/dokumenter/meld.-st.-2820152016/id2483955/

Utdanningsdirektoratet om Kjerneelementer 2017. https://www.udir.no/laringog-trivsel/lareplanverket/fagfornyelsen/kjerneelementer/

Opplæringslovens formålsparagraf. https://www.udir.no/lk20/overordnet-del/ formalet-med-opplaringen/

"Hva er nytt i fagene» Utdanningsdirektoratets kunngjoring, KRLE. 2020. https://www. udir.no/laring-og-trivsel/lareplanverket/fagfornyelsen/hva-er-nytt-fageneles-vare-korte-oppsummeringer/\#147427

Lareplanverket 2020. Overordnet del. https://www.udir.no/lk20/ overordnet-del/opplaringens-verdigrunnlag/1.2-identitet-og-kultureltmangfold $/$ ?kode $=$ rle $01-03 \&$ lang $=$ nob

Lareplan KRLE 2020. https://data.udir.no/k106/v201906/laereplaner-lk20/ RLE01-03.pdf?lang=nob

\section{Sekundærlitteratur}

Alver, Brynjulf: «Tradisjon» i Store norske leksikon på snl.no. Hentet 20. oktober 2020 fra https://snl.no/tradisjon

Anker, Trine. 2017. På tide å si farvel til verdensreligionene? I Von der Lippe og Undheim 2017, s. 25-34 
Breilid, Halldis og Nicolaisen, Tove. 2011. I begynnelsen var fortellingen. 2011. Oslo: Universitetsforlaget. (2. utg.; 1. utg. i 2000)

Bøe, Marianne Hafnor og Anne Kalvig. 2020. Mennesker, meninger, makter. En introduksjon til religionsvitenskap. Oslo: Cappelen Damm Akademisk

Gravem, Peder. 2004. KRL - Et fag for alle? KRL-faget som svar på utfordringer i en flerkulturell enhetsskole, Oplandske Bokforlag

Green, Nancy L. 2004. «Forms of Comparison.» I Deborah Cohen og Maura O'Connor (red.): Comparison and History. Europe in Cross-National Perspective. Abingdon: Routledge

Huse, Hedda. 2017. Innledningen fra om kjerneelementer 12. -13.06.2017 https://www.udir.no/laring-og-trivsel/lareplanverket/fagfornyelsen/ utgatte-saker/samlinger-om-kjerneelementer/filmer-om-fagfornyelsen/ ulike-perspektiver-pa-kjerneelementer-og-koblinger-til-kompetansebegrepet-og-dybdelaring/

Jackson, Robert. 2009/2012. Studying Religions. The Interpretive Approach in Brief. https://theewc.org/content/uploads/2020/02/Studying-ReligionsThe-Interpretive-Approach-in-Brief.pdf

Kulturarv, Stiftelsen Norsk Kulturarv http://www.kulturarv.no

Kværne, Per. «Religionsfenomenologi» i Store norske leksikon på snl.no. Hentet 9. september 2020 fra https://snl.no/religionsfenomenologi

Von der Lippe, Marie og Undheim, Sissel (red.). 2017. Religion i skolen. Didaktiske perspektiver på religions- og livssynsfaget. Oslo: Universitetsforlaget

Oexle, Otto Gerhard \& Jörn Rüsen (red.). 1996. Historismus in den Kulturwissenschaften (= Beiträge zur Geschichtskultur Bd. 12), Köln: Böhlau Verlag

Rasmussen, Tarald og Thomassen, Einar. 1999. Kildesamling til kristendomskunnskap med religions- og livssynsorientering. Oslo: Nasjonalt læremiddelsenter. 2 bind. Varig lenke: https://urn.nb.no/URN:NBN:no-nb_digibok_2010120206018

Stange, Edvard. 1999. KRL-97. Nytt fag i grunnskolen. Kompromiss eller overtramp? Kristiansand: Høgskoleforlaget

Sødal, Helje Kringlebotn; Hodne, Hans; Repstad, Pål og Tallaksen, Inger Margrethe. 2018. Religioner og livssyn i skolehverdagen. Oslo: Cappelen Damm Akademisk

Wintersgill, Barbara (utg.). 2017. Big Ideas for Religious Education, University of Exeter. Pdf.: Big_Ideas_for_RE_E-Book.pdf 